Plasma 11-OHCS and Questionary Results (Means \pm S. D.)

\begin{tabular}{|c|c|c|c|c|c|c|}
\hline $\mathrm{N}$ & Basal & $\begin{array}{c}\text { Post } \\
\text { Dexa- } \\
\text { methasone }\end{array}$ & $\begin{array}{l}\text { M. Plasma 11- } \\
\text { ( } \mu \mathrm{g} . / 100 \mathrm{~m} \\
\text { Zung Self } \\
\text { Rating } \\
\text { Score }\end{array}$ & $\begin{array}{l}\text { HCS } \\
\text { Hamilton } \\
\text { Depression } \\
\text { Score }\end{array}$ & $\begin{array}{c}\text { Taylor } \\
\text { Anxiety } \\
\text { Score }\end{array}$ & $\begin{array}{c}\text { N Score Eysenck } \\
\text { Personality } \\
\text { Inventory }\end{array}$ \\
\hline 10 & $\begin{array}{c}21 \cdot 4 \\
(6 \cdot 9)\end{array}$ & $\begin{array}{c}4 \cdot 4 \\
(1 \cdot 4)\end{array}$ & $\begin{array}{c}54 \cdot 3 \\
(9 \cdot 0)\end{array}$ & $\begin{array}{c}21.3 \\
(3.9)\end{array}$ & $\begin{array}{l}32 \cdot 6 \\
(7 \cdot 8)\end{array}$ & $\begin{array}{l}17 \cdot 3 \\
(4 \cdot 0)\end{array}$ \\
\hline 6 & $\begin{array}{l}19.9 \\
(6.8)\end{array}$ & $\begin{array}{l}19 \cdot 1 \\
(5 \cdot 8)\end{array}$ & $\begin{array}{c}54 \cdot 6 \\
(13 \cdot 2)\end{array}$ & $\begin{array}{l}22 \cdot 0 \\
(5 \cdot 3)\end{array}$ & $\begin{array}{l}27 \cdot 1 \\
(8 \cdot 9)\end{array}$ & $\begin{array}{l}18 \cdot 4 \\
(2 \cdot 8)\end{array}$ \\
\hline
\end{tabular}

At the end of one month the ten suppressors were well, all having responded to the particular antidepressant drug and not having relapsed, at that time, with placebo substitution. The six non-suppressors, after one month's antidepressant treatment had not improved and were all then treated with E.C.T. with subsequent improvement.

This small study suggests that poor shortterm response to antidepressants is related to hypothalamic dysfunction. This lack of response and the presence of hypothalamic dysfunction could not have been predicted from clinical or questionary data. Further studies of specific treatment responses and tests of hypothalamic function are needed in depressed patients. If these findings are

replicated, they may be of clinical value in deciding on appropriate treatment for the particular patient and may help in elucidating the action of antidepressants.-We are, etc.,

\section{Department of Psychiatry, \\ Royal Melbourne Hospital Victoria, Australia.}

\section{Carroll, B. J., Martin, F, I}

Carroll, B. J., Martin, F. I. R. and Davies B. British Medical fournal, 1968, 3, 285.
Carroll, B. J., British Medical fournal, 1969, 3, 27. British Medical fournal, 1970, 1, 644.

\section{Perioral Dermatitis}

SiR,-Drs. J. L. Verbov and E. Abell (6 December, 1969 , p. 621 ) have suggested that the syndrome which has become known as perioral dermatitis is iatrogenic. They base this suggestion on their observation that their patients with this syndrome had been applying a topical corticosteroid.

We join in deploring the current abuse of corticosteroids, which has reached such proportions that few patients referred to dermatological departments with any skin disorder have not been so treated. Drs. Verbov and Abell have not, however, established the nature of the condition from which their patients were suffering before the corticosteroids were prescribed.

In the past eight weeks we have examined 25 patients with perioral dermatitis. Six of the patients had not applied a corticosteroid before their first attendance. Of the remaining 19 patients, 17 gave a clear account of lesions compatible with perioral dermatitis present for from two weeks to four months before corticosteroids were first prescribed. One patient had used corticosteroids intermittently for acne and one for a rash not reliably indentifiable from her description of the lesions. Dr. $\mathrm{N}$. Hjorth from the Finsen Institute, Copenhagen, writes in a personal communication that his experience and conclusions agree with our own.

Topical steroids can provoke pustular episodes in acne and 1osacea, and they may aggravate perioral dermatitis, but they cannot be incriminated as the cause of that syndrome. Though a rebound exacerbation may occur when the steroids are discontinued we have found the condition relatively easy to cure with oral tetracyclines.-We are, etc.,

\section{Cambridge}

A. J. Rook.

Amersham, Bucks.

\section{S. WILKINSON.}

\section{W. R. MCLEOD.}

\section{B. J. Carroll.}

Brian Davies.

results had created a rather intriguing situation in which we decided to test the sensitivity to clindamycin of 50 freshly isolated and correctly identified $H$. influenzae strains. In our hands the M.I.C.s fell within the limits of 0.12 to $4.0 \mu \mathrm{g} . / \mathrm{ml}$., and 42 strains $(84 \%)$ were sensitive to 2 $\mu \mathrm{g} . / \mathrm{ml}$. or less. Our investigations did not explain the discrepancies in the literature, nor were they designed to do so. Nevertheless, as peak serum levels of clindamycin are about $6 \mu \mathrm{g} . / \mathrm{ml}$. and average levels are about $3 \mu \mathrm{g} . / \mathrm{ml}$. the possibility exists that this drug may be of use in bronchitis with $H$. influenzae as a pathogen. No certain prediction one way or the other, however, can be made at this stage as any valid statement is dependent on adequate sputum levels still to be determined, perhaps followed by comparative and double-blind clinical trials in bronchitis.

We felt, therefore, that the true situation regarding the new lincomycin derivative should be placed before the readers of the B.M.F. None of the considerations outlined above are applicable to the considerable inhibiting action it has on other potential pathogens in bronchitis-i.e., Staphylococcus aureus, pneumococci, and beta-haemolytic streptococci.

It is perhaps of some interest that erythromycin, according to our results, ${ }^{5}$ is of considerable in-vitro activity against $H$. influenzae, and may deserve a place in the armametarium against bronchitis, particularly when combined with a sulphonamide. ${ }^{0}-$ We are, etc.,

\section{K. ZiNNEMANN.} JOYCE FRAZER.

\section{Bacteriology Department.}

Leeds, Yorks

\section{REFERENCES}

Meyers, B. R., Kaplan, K., and Weinstein, L. Applied Microbiology, 1969, 17, 653

作, nal of the Medical Sciences, 1968 256, 314

Garrison, D. W., DeHaan, R. M., and Lawson, J. B., An 397

4 McGehee, R. F., jun., Smith, C. B., Wilcox, C. and Finland, M., American Fournal of the Medical Sciences, 1968, 256, 279.

5 Zinnemann, K., Ergebnisse der Mikrobiologie, Immunotäts-forschung und Experimentall

6 Allibone, E. C., Allison, P. R., and Zinnemann

\title{
Chemotherapy of Bronchitis
}

SIR,-The action of clindamycin on Haemophilus influenzae, among other microorganisms, has been brought into focus once more by the recent paper of Dr. I. Phillips and others (11 April, p. 89). Moreover, you leading article on chemotherapy of bronchitis (17 January, p. 125) in its final paragraph assumes that, among other antibacterial drugs, 7-chloro-7-deoxy-lincomycin (clindamycin, Dalcacin) offers little or no advantage in the treatment of bronchitis, similar to erythromycin. It is disturbing to the scientifically minded that this assumption has not been declared as such, but is stated as a safe prediction-almost as a fact-although at present there is inadequate evidence for such prediction.

The usefulness of an antibacterial drug depends on several features. These are absence of serious side-effects, good absorption, maintenance of adequate blood levels for an adequate length of time, low serum protein binding, adequate concentrations in tissues or body fluids at or near the site of infection, and minimum inhibitory concentrations (M.I.C.) of the drug for pathogenic microorganisms within the range of levels obtainable in body fluids and tissues. $\mathrm{Al}$ though in the case of clindamycin many of these factors are favourable, so far only serum levels but not lung tissue or sputum levels obtainable with his drug have been reported.

Meyers et al. ${ }^{1}$ reported M.I.C.s for $H$. influenzae ranging from 1.2 to $3.0 \mu \mathrm{g} . / \mathrm{ml}$ and Oppenheimer and Turck $^{2}$ from 0.5 to $5.0 \mu \mathrm{g} . / \mathrm{ml}$; in other words, well within the range of peak and average serum levels. However, the M.I.C.s recorded in other observations, including those of Dr. Phillips and colleagues, were rather high, ranging from 3.0 to $50.0 \mu \mathrm{g} . / \mathrm{ml}^{3}{ }^{4}$ These conflicting
SIR-After reading the recent article by Dr. I. Phillips and his colleagues (11 April, p. 89) it would seem that any possible role for 7-chloro-lincomycin (clindamycin) in the treatment of bronchitis would depend on its activity against Haemophilus influen$z a e$, and its ability to produce inhibitory concentrations in sputum.

I have recently carried out a small series of investigations with clindamycin, the results of which might be of interest at this stage. Of 12 strains of $H$. influenzae tested, five had a minimal inhibitory concentration (M.I.C.) of less than $1.0 \mu \mathrm{g} . / \mathrm{ml}$, and the most resistant were inhibited by $4.0 \mu \mathrm{g} . / \mathrm{ml}$. In comparison, the M.I.C. of lincomycin for the 12 strains was $8.0 \mu \mathrm{g} . / \mathrm{ml}$.

The results of sputum levels have been determined in five patients and are as follows : 


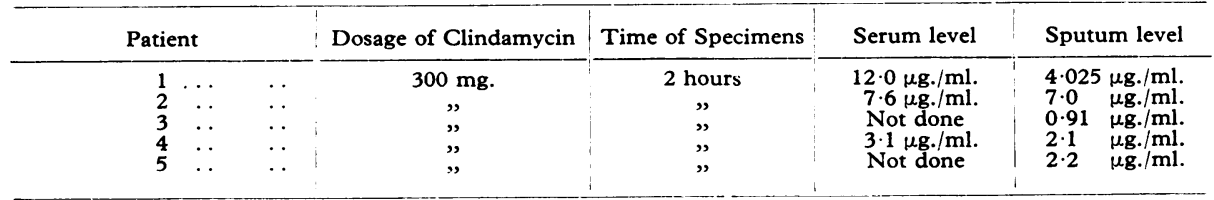

It would seem therefore that serum and sputum levels can be achieved sufficient to inhibit $H$. influenzae.-I am, etc., Department of Bacteriology,

Law Hospital,
ARThur A. B. Mitchell. Carluke, Lanarks.

\section{Another Paraquat Fatality}

SIR,-We wish to record a further instance of fatal paraquat poisoning. So far as we can ascertain, this is the tenth reported fatality caused by this widely used herbicidal preparation..$^{1-4}$ In December 1965 42-year-old male accidentally drank a smal quantity of "weed-killer" from an unlabelled stout bottle. It was later estimated that the quantity of fluid consumed was about threequarters of a teaspoonful. The nature of the substance could not be immediately ascertained, but it was subsequently identified as Gramaxone $19 \% \mathrm{w} / \mathrm{w}$ paraquat ion) by the laboratories of I.C.I. Ltd. On admission to hospital a few hours after taking the poison, the patient complained of a burning sensation in the throat and repeated vomiting. Despite immediate gastric lavage, prophylactic penicillin, and abundant oral and intravenous fluids, there was progressive clinical deterioration. At three days the tongue was severely ulcerated and two days later haemoptysis occurred. On the eighth day jaundice, pyrexia, tachycardia, and a blood urea of $375 \mathrm{mg} . / 100 \mathrm{ml}$. were recor- ded. The patient died some hours later.

The outstanding necropsy findings included focal myocardial necrosis, severe pulmo nary haemorrhage and oedema, dense eosinophilic alveolar membrane, and proliferation of fibroblast-like cells in the alveolar septa.

It is apparent from this and other reports that the lethal dose of paraquat may be very small. Further fatalities will only be avoided by proper care in the storage and use of this valuable but potentially dangerous compound. A detailed and illustrated clinico-pathological report is being prepared for publication.-We are, etc.,

\section{Department of Pathology, J. G. MASTERSON.} University College, Dublin 2 .

St. Columcille's Hospital, W. J. RocHE. Loughlinstown

\section{REFERENCES}

1 Almog, Ch., and Tal, E., British Medical .fournal, 1967, 3, 721. 1,1272 .

3 Campbell, S., Lancet, 1968, $1,144$. Oreopoulos, D. G., et al., British Medical Journal
1968, 1, 749.

\section{Drugs in Depressive Illness}

SIR,-I was interested to read the article by Dr. A. M. Porter (28 March, p. 773). In his discussion he concluded that his work provided evidence to suggest that the milder forms of depression may be effectively treated with support and a placebo. One of the difficulties he mentioned in carrying out a drug trial with placebo was the easy breach of the cipher when drugs like imipramine were used because of their side-effects, and suggested the possibility of adding atropine to the placebo tablets to avoid this difficulty. This possibility has been discussed previously in a critical view of antidepressant drug trials. ${ }^{1}$ This review also mentioned that most depressed patients get better anyway, and the patients who improve after being prescribed tablets have done post hoc, but not necessarily propter hoc.

In a double-blind drug trial carried out in this hospital for which preliminary results are now available, 54 patients entered the trial and of these 15 were treated with a tablet containing amitriptyline and perphenazine (Triptafen), 20 with perphenazine (Fentazin), and 19 with a placebo containing atropine. Each of the patients was randomly allocated to one of the treatments and assessed on three occasions in terms of 15 symptoms plus an overall rating. The trial and its analysis are still continuing.

\begin{tabular}{|c|c|c|c|}
\hline $\begin{array}{c}\text { Degree of } \\
\text { Improvement }\end{array}$ & Triptafen & Fentazin & Placebo \\
\hline $\left.\begin{array}{l}\text { Worse } \\
\text { Unchanged } \\
\text { Improved } \\
\text { MuchImproved } \\
\text { Recovered }\end{array}\right\}$ & $\left.\begin{array}{c}2 \\
2 \\
0 \\
1 \\
10\end{array}\right\} 11$ & $\left.\begin{array}{r}1 \\
4 \\
0 \\
4 \\
11\end{array}\right\} 15$ & $\left.\begin{array}{l}5 \\
3 \\
4 \\
5 \\
2\end{array}\right\} 11$ \\
\hline
\end{tabular}

$\chi$ was evaluated after pooling the "worse" and "unchanged" categories.

The Table shows the distribution of patients according to their degree of improvement at the final assessment. A statistical analysis shows that $\chi^{2}=1.52$, implying a lack of significant difference between the various treatments. Although these patients were from hospital practice, the results are certainly very similar to those of Dr. Porter, and of Hunter et al. ${ }^{2}$, and would support the view that antidepressant drugs tend to become established in clinical practice on inadequate evidence.-I $\mathbf{I}$ am, etc.,

\section{ZULFIQUAR HUSSAIN.}

Cherry Knowle Hospital, Sunderland,
Co. Durham

\section{REFERENCES}

1 Leyburn, P., Lancet, 1967, 2, 1135.

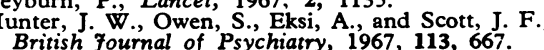

\section{Blue Light and Jaundice}

SIR,-Inasmuch as I am an "enthusiastic" supporter of phototherapy, I feel that I should comment on the ultra-conservative editorial comment, "Blue Light and Jaundice" (4 April, p. 5).

Workers in this field ${ }^{2}$ now recognize that bilirubin can produce learning difficulties in humans at lower serum concentrations than were previously realized. Previous studies have not detected these defects because of inadequate testing. It is for this reason that a safe and simple method to replace exchange transfusion is needed. The statement that phototherapy is "unlikely to be adequate treatment" in preventing low bilirubin kernicterus is an opinion with which I certainly do not agree. Preliminary data suggest that this is the type of infant who will benefit. Phototherapy is also now widely being used to control mild haemolytic disease. There has been no convincing evidence published to support the original suggestion by Franklin ${ }^{3}$ that the photochemical products might be toxic. There is considerable evidence that these products are not toxic either in vivo, in vitro, and in human infants. ${ }^{4} I$ would ask that the author of this leading article and others read the Bilirubin Symposium ${ }^{4}$ quoted, and not just the summary as has apparently been done, for more data on this important point. I would also refer the reader to two recent articles, ${ }^{5}$ for more reassuring evidence in human infants. Published human clinical experience for several countries with phototherapy now numbers over 5,000 cases, and no serious toxic effects have been reported to date. More recent studies in two human infants with Crigler-Naijar syndrome employing ${ }^{14} \mathrm{C}$ labelled bilirubin and phototherapy indicate that the breakdown products are rapidly and safely excreted. ${ }^{8}$

Early feeding may have limited the incidence of hyperbilirubinemia of prematurity in one nursery in England to less than 1\%, but this has certainly not been the experience in the U.S.A. Where this problem has been studied carefully, one usually finds that from $10-25 \%$ of premature infants can be expected to develop serum bilirubin concentrations of over $15 \mathrm{mg} . / 100$ $\mathrm{ml}^{7}$

The leader writer also cites a reference ${ }^{9}$ referring to a hypothesis that light might cause retrolental fibroplasia. This curious theory is certainly not widely held by many paediatricians.

I, and others, have not used "blue" light, but have employed broad spectrum light. One should not of course use "blue light," especially if you want to judge skin colour. Phototherapy units are now designed so that they not only allow better observation of the infant but also free access to the infant. The leader writer's quaint reluctance to allow even a minor change in the present lighting conditions in the nursery suggests that he knows that these conditions are indeed optimal for newborn infants. I challenge this idea. I am afraid that few doctors actually have any idea about the present lighting conditions in their nursery. Outdoor light on a bright day supplies 10,000 foot candles of broad spectrum light. I have found nurseries with 25 foot candles to 2,000 foot candles in the same nursery. Phototherapy units supply only about $300-500$ foot candles of light. "Phototherapy" is, 